\title{
Evaluation of polanga (Calophyllum inophyllum) oil cake as a non-conventional ingredient in Labeo rohita (Hamilton, 1822) fingerling feed
}

\author{
S. C. RATH, K. C. NAYAK, C. PRADHAN, T. K. MOHANTY, S. SARKAR, S. TOPPO, \\ K. N. MOHANTA AND S. S. GIRI \\ ICAR-Central Institute of Freshwater Aquaculture, Bhubaneswar - 751 002, Odisha, India \\ e-mail: scrathcifa@yahoo.com
}

\begin{abstract}
In the present study, polanga (Calophyllum inophyllum) oil cake (POC) was evaluated as a non-conventional ingredient in Labeo rohita (Hamilton, 1822) fingerling feed. Proximate composition and fatty acid analysis of POC indicated that it can be a good source of protein $(24.2 \%)$ and energy $\left(4.4 \mathrm{kcal} \mathrm{g}^{-1}\right)$. Fatty acid analysis indicated that it is dominated by monoenes (39\%) followed by saturates (28.42) and polyunsaturated fatty acids (PUFA) n-6 (27.76\%). Further, phenol, tannin and flavonoids were detected as prominent secondary metabolites. Five iso-nitrogenous $(25-26 \%$, crude protein) feeds incorporated with POC @ 0\% (F1), 10\% (F2), 20\% (F3), 30\% (F4) and 40\% (F5) level were fed to L. rohita fingerlings for 90 days in indoor conditions. At the end of the experiment, it was observed that survival percentage (95-97\%) of F1, F2 and F3 groups was statistically similar which was significantly higher $(p<0.05)$ compared to F4 and F5. The gain in weight and specific growth rate (SGR) of F1 and F2 were similar but next higher inclusion levels of POC significantly $(\mathrm{p}<0.05)$ reduced the growth in F3, F4 and F5 groups. In addition, feed conversion ratio (FCR) was significantly lower $(\mathrm{p}<0.05)$ and similar in F1 and F2. Protein efficiency ratio (PER) and net protein utilisation (NPU) were found significantly higher $(\mathrm{p}<0.05)$ in F1 and F2 as compared to the rest of the groups. Haemoglobin, serum protein, albumin and globulin in blood were similar in F1 and F2 ( $>0.05$ ), which were significantly higher than the levels in other groups $(\mathrm{p}<0.05)$. Serum glutamic-oxaloacetic transaminase (SGOT) and glucose levels increased significantly in F3, F4 and F5 groups compared to F1 and F2. POC was used for the first time in carp feeds as a non-conventional feed ingredient during this study and the results clearly indicated that POC could be incorporated @ $100 \mathrm{~g} \mathrm{~kg}^{-1}$ in the feed of $L$. rohita fingerlings without any adverse effect on growth, survival and nutrient utilisation.
\end{abstract}

Keywords: Calophylum innophylum, Feed, Labeo rohita, Polanga oil cake

\section{Introduction}

Aquaculture in pond needs suitable supplementary feed for sustainable production. Feed constitutes more than $60 \%$ of total operational cost in aquaculture (Mohanty et al., 2011). The traditional ingredients used in aquafeeds are getting costlier and competitive as being used for different animal production systems. Therefore, inclusion of newer non-conventional feed ingredients could help to develop cost effective feeds. Fish need more protein in their diet than land animals and so aquafeed requires protein rich ingredients (Hasan et al. 2007). Plant proteins are used as sole dietary protein for carps. Soybean meal and groundnut oil cakes are the major plant proteins used in compounded aquafeeds followed by other oil cakes (Barman and Karim, 2007; Manomaitis, 2009). It is therefore suggested to explore newer non-conventional plant feed resources for formulating cost effective carp feeds (FAO, 2010).

Alexanderian laurel (Calophyllum inophyllum), commonly known as Indian doomba or polanga, belongs to
Clusiaceae (or Guttiferae) family. It is an evergreen tree found in the tropical coastal climate and is often planted under the avenue plantation and afforestation programmes. The fruit bears a seed inside a corky shell covering. The oil recovery is around 50\% from the seed and rest is cake (Mohanty et al., 2013). Polanga oil cake (POC) is not yet rationally used as feed ingredient. Scanty information is available on the use of this oil cake in the feed for poultry (Behura et al., 1987; Dash et al., 1990; Sahu et al., 1993; Mohapatra and Samal, 2002; Mishra et al., 2005). However, no literature is available on the use of POC as fish feed ingredient. Therefore, the objective of the present study was to generate information on nutritive values, anti-nutritional factors, acceptability and optimum level of incorporation of raw polanga oil cake in carp feed.

\section{Materials and methods}

Feed, fish and experimental design

POC from the local oil mill was collected and analysed for its proximate composition in National Fish Feed Testing Laboratory at ICAR-Central Institute of Freshwater 
Aquaculture (ICAR-CIFA), Bhubaneswar, India. In addition, the POC was subjected to qualitative detection of secondary metabolites viz., tannin, phenol, alkaloids, flavonoids, saponins and glycosides. Five isonitrogenus (25-26\% CP) feeds (F1-F5) were formulated incorporating raw POC meal at $0 \%(\mathrm{~F} 1), 10 \%(\mathrm{~F} 2), 20 \%(\mathrm{~F} 3), 30 \%(\mathrm{~F} 4)$ and $40 \%(\mathrm{~F} 5)$ levels with groundnut oil cake, rice bran, wheat flour and vitamin and mineral premix (Supplevite-M, Jeco Vet Chem Pvt. Ltd, India) as co-ingredients (Table 1). Feed pellets of $2 \mathrm{~mm}$ dia were made with portable mechanical pelletiser and oven dried at $60^{\circ} \mathrm{C}$. Pellets were crumbled to $0.5 \mathrm{~mm}$ size and stored in air tight plastic containers.

\section{Proximate composition and fatty acid analysis}

Proximate composition of POC, experimental diets and whole body carcass of the fish was determined according to AOAC (1990). Fiber content of the feed was determined using fiber tech and gross energy was determined by bomb caloriemeter (IKA Caloriemeter system, C5000 control). In addition, fatty acid composition was analysed for POC, feeds and fish whole body carcass samples. Lipids from the sample were extracted by adding $(2: 1 \mathrm{v} / \mathrm{v})$ chloroform-methanol mixture containing $0.01 \%$ butylated hydroxytoluene (BHT) (Folch et al., 1957). The weight of lipids was determined

Table 1. Chemical composition of polanga (Calophyllum inophyllum) oil cake (\% dry matter, DM basis)

\begin{tabular}{|c|c|c|c|c|c|}
\hline \multicolumn{6}{|l|}{ Nutrients } \\
\hline Moisture & Crude protein & Crude lipid & Crude fiber & Ash & Nitrogen free extract (NFE) \\
\hline 70 & 24.2 & 9.3 & 7.6 & 6.0 & 52.7 \\
\hline \multicolumn{6}{|c|}{ Phytochemicals } \\
\hline $\begin{array}{l}\text { Tannin } \\
+++ \\
\end{array}$ & $\begin{array}{l}\text { Phenol } \\
+++\end{array}$ & $\begin{array}{l}\text { Alkaloid } \\
+\end{array}$ & $\begin{array}{l}\text { Flavonoid } \\
++\end{array}$ & $\begin{array}{l}\text { Saponin } \\
+\end{array}$ & $\begin{array}{l}\text { Glycoside } \\
+\end{array}$ \\
\hline \multicolumn{6}{|c|}{ Fatty acids $(\%)$} \\
\hline$\sum \mathrm{SFA}$ & $\sum$ MUFA & $\sum$ PUFA n-6 & $\sum$ PUFA n-3 & Total & \\
\hline 28.427 & 39.357 & 27.7675 & 0.3895 & 95.941 & \\
\hline
\end{tabular}

+ detected, ++ moderately detected, +++ adequately detected

The experiment was conducted at the wet laboratory of the ICAR-CIFA during November 2013 February 2014. Fifteen flow-through cement tanks (300 1), with a flow rate of $0.51 \mathrm{~min}^{-1}$, were used for rearing Labeo rohita (Hamilton, 1822) fingerlings (average $5 \mathrm{~g}$ ) in triplicates. Each tank was stocked with 22 fingerlings and the experiment was carried out for 90 days. Fish were fed ad libitum, twice daily at 0900 and 1600 hrs with the test feeds. The leftover feed was siphoned out after $2 \mathrm{~h}$ of feeding, dried and weighed to calculate the daily feed intake. Fish were weighed at monthly intervals and routine water quality parameters, viz., temperature, transparency, total alkalinity, hardness un-ionised ammonia, dissolved oxygen and $\mathrm{pH}$ were monitored twice a week as per APHA (1989). Proximate composition and fatty acid analysis of POC, test feeds, initial and final carcass were determined. At the end of the experiment, blood was drawn by caudal vein puncture from ten fish sampled from each group. A part of blood was collected in heparinised vial for whole blood haemoglobin assay and rest was allowed to clot in normal vial for serum collection. The serum was separated by centrifugation (5000 rpm, $5 \mathrm{~min}$ ). Haemoglobin was determined immediately whereas, serum samples were pooled treatment-wise and kept at $-20^{\circ} \mathrm{C}$ for further analysis. gravimetrically after evaporation of the solvent. Fatty acid methyl esters (FAME) were prepared by acid-catalysed transesterification of total lipids according to the method of Christie (1982). Fatty acid methyl esters were separated by a gas chromatograph equipped with a flame-ionisation detector (Shimadzu GC-2010, Kyoto, Japan) on a DB- 25 capillary column $(20 \mathrm{~m} \times 0.10 \mathrm{~mm}$ I.D., $0.10 \mu \mathrm{m} \mathrm{J}$ and W Scientific, Santa Clara, CA, USA). The fatty acids were identified using fatty acid methyl ester (FAME) standards. Area percentage normalised values for the fatty acids were taken as weight percentage.

\section{Qualitative analysis of phytochemicals}

Qualitative estimation of phytochemicals (alkaloids, sterol, flavanol, flavonoids, phenol, tannin, glycoside and saponin) was done. Extract was prepared with n-hexane, ethyl acetate and methanol and analysed using the standard protocol as described by Harbone (1998) and Evans (2000).

Test for alkaloids: About $0.2 \mathrm{~g}$ of dry extracts of the sample was boiled with $5 \mathrm{ml}$ of $2 \% \mathrm{HCI}$ on a steam bath for $10 \mathrm{~min}$. The mixture was filtered and $1 \mathrm{ml}$ of the filtrate measured into a test tube. Each $1 \mathrm{ml}$ filtrate was treated with 2 drops of Wagner's regent (1.27 $\mathrm{g}$ of iodine and $2 \mathrm{~g}$ of potassium iodide in $100 \mathrm{ml}$ water). A reddish brown precipitate indicated the presence of alkaloids. 
Test for flavonoids: About $0.2 \mathrm{~g}$ each of the dry extracts was heated with $10 \mathrm{ml}$ of ethyl acetate in boiling water for $3 \mathrm{~min}$. The mixture was filtered consecutively and the filtrates used for aluminum chloride test, for which $4 \mathrm{ml}$ of the filtrates was shaken with $1 \mathrm{ml}$ of $1 \%$ aluminum chloride solution. A yellow precipitate indicated the presence of flavonoids.

Test for glycosides: Legal's test was carried out for detection of glycosides. The extract $(0.1 \mathrm{~g})$ was treated with $\mathrm{NaOH}$ solution and formation of a pink to red colour solution indicated the presence of glycosides.

Test for saponin: Saponins were determined using the frothing test. About $1 \mathrm{ml}$ of the extract was diluted with $4 \mathrm{ml}$ of distilled water and the mixture was shaken vigorously and then observed on standing for a stable froth.

Test for phenol: About $2 \mathrm{ml}$ aqueous extract was stirred with two drops of solution $\mathrm{A}\left[10 \%\right.$ ferric chloride $\left(\mathrm{FeCl}_{3}\right)$ and $1 \%$ ferric cyanide $\left.\left(\mathrm{FeCN}_{6}\right)\right]$ and two drops of solution $\mathrm{B}[1 \%$ ferric chloride and $1 \%$ potassium ferric cyanide $\left(\mathrm{K}_{3} \mathrm{Fe}_{3} \mathrm{CN}_{3}\right)$ ] at $110^{\circ} \mathrm{C}$. Change in colour of the extract to blue indicated presence of phenol.

Test for tannin: About $2 \mathrm{ml}$ of distilled water and a few drops of $\mathrm{FeCl}_{3}$ solution were added to the extract. The formation of a green precipitate indicated the presence of tannins.

Test for sterols: Sterols were determined using sulfuric acid test. The fraction of extract was treated with ethanol and $\mathrm{H}_{2} \mathrm{SO}_{4}$. Formation of violet blue or green colour indicated the presence of sterols.

\section{Haematological analysis}

Blood samples were analysed for haemoglobin (Van Kampen and Zijlstra, 1961). Serum glucose was estimated as per method of Kaplan (1984). The sera samples were also used for determining total protein (Flack and Woollen, 1984), albumin (Doumas, 1971). Globulin was determined by subtracting albumin from total serum protein. In addition, sera samples were also analysed for triglycerides (McGowan et al., 1983), cholesterol (Allain, 1974), high density lipoprotein (HDL) and low density lipoprotein (LDL) (Burtis and Ashwood, 1994). Very low density lipoprotein (VLDL) was calculated by dividing the triglyceride value with 5 and expressed as $\mathrm{mg} \mathrm{dl}^{-1}$. Serum glutamic-oxaloacetic transaminase (SGOT) and serum glutamic-pyruvic transaminase (SGPT) activities were determined using Greiner diagnostic kits (Bahlingen, Germany) (Bergmeyer, 1974).

\section{Data collection and analysis}

Fish were weighed at monthly intervals to ascertain the growth parameters. The weight gain (\%), specific growth rate
(SGR), food conversion ratio (FCR), protein efficiency ratio (PER), net protein utilisation (NPU) and survival rate (\%) were calculated as detailed below:

$$
\begin{array}{ll}
\text { Weight gain }(\%) & =\frac{\text { (Final weight }- \text { Initial weight })}{\text { Initial weight }} \times 100 \\
\text { SGR } & =\frac{\text { ln Final weight }- \text { ln Initial weight }}{\text { Days of experiment }} \times 100 \\
\text { FCR } & =\frac{\text { Feed consumed (dry weight) }}{\text { Live weight gain (wet weight) }} \\
\text { PER } & =\frac{\text { Live weight gain }}{\text { Protein consumed }} \\
\text { NPU }(\%) & =\frac{\text { Protein gain in carcass }}{\text { Protein intake in food }} \times 100 \\
\text { Survival rate }(\%) & =\frac{\text { Initial no. of larvae }- \text { Final no. of fry }}{\text { Initial no. of larvae }} \times 100
\end{array}
$$

Data were analysed using one way ANOVA (Snedecor and Cochran, 1967) and difference between means were tested using Duncan's multiple range test.

\section{Results}

The water quality parameters recorded in the experimental tanks were as follows: temperature, $25-27^{\circ} \mathrm{C}$; transparency, $25-28 \mathrm{~cm}$; total alkalinity $\left(\mathrm{CaCO}_{3}\right)$, 90-110 $\mathrm{mgl}^{-1}$; hardness, 80-96 $\mathrm{mgl}^{-1}$; un-ionised ammonia, $<0.1 \mathrm{mgl}^{-1}$; dissolved oxygen, $5-7 \mathrm{mgl}^{-1}$ and $\mathrm{pH}, 7.5-8.5$. The chemical composition of POC is presented in Table 1. It contained $24 \% \mathrm{CP}$ and $4.4 \mathrm{kcal} \mathrm{g}^{-1}$ energy. Table 2 presents the chemical composition of all the five test feeds (F1-F5).

The feeds were iso-nitrogenus with $25-26 \%$ protein. The incorporation of POC in the experimental feeds replaced the groundnut oil cake at 4, 7, 10 and $13 \mathrm{~g}$ and rice bran at 6, 13, 20 and $27 \mathrm{~g}$ per $100 \mathrm{~g}$ of F2, F3, F4 and F5 feeds, respectively. Survival, growth, nutrient utilisation, weight gain and whole body composition of L. rohita fingerlings under different test feeds are presented in Tables 3 and 4 , respectively. At 0,10 and $20 \%$ inclusion levels of POC (F1- F3), survival rate was significantly $(\mathrm{p}<0.05)$ higher (95-97\%) than that of $30-40 \%$ inclusion (F4-F5), where the survival was $<85 \%$. The SGR ( $\%$ growth day ${ }^{-1}$ ) was statistically similar in F1 and F2 and significantly higher $(p<0.05)$ than other groups. Weight gain $(\%)$ was significantly higher $(\mathrm{p}<0.05)$ in fingerlings fed with $\mathrm{F} 1$ and F2 feeds than the other test feeds. FCR was significantly lower $(p<0.05)$ in F1 and F2 than rest of the feeds. PER and NPU were also significantly higher $(\mathrm{p}<0.05)$ in $\mathrm{F} 1$ and $\mathrm{F} 2$ compared to all other test feeds. The final whole body protein content was alike ( $p>0.05$ ) up to $10 \%$ POC inclusion level (F1 to F2) and thereafter, it decreased significantly $(\mathrm{p}<0.05)$ in F3 to F5 (Table 3). 
Table 2. Composition of the test feeds of Labeo rohita fingerlings incorporating polanga oil cake at different levels as non-conventional ingredient (\% DM basis)

\begin{tabular}{|c|c|c|c|c|c|}
\hline \multirow{2}{*}{ Ingredients } & \multicolumn{5}{|c|}{ Test feeds of L. rohita } \\
\hline & $\mathrm{F} 1$ & $\mathrm{~F} 2$ & F3 & $\mathrm{F} 4$ & F5 \\
\hline POC & 0 & 10 & 20 & 30 & 40 \\
\hline GNOC & 37 & 33 & 30 & 27 & 24 \\
\hline $\mathrm{RB}$ & 59 & 53 & 46 & 39 & 32 \\
\hline Vitamin-mineral pre-mix* & 2 & 2 & 2 & 2 & 2 \\
\hline Wheat flour & 2 & 2 & 2 & 2 & 2 \\
\hline \multicolumn{6}{|l|}{ Proximate composition } \\
\hline Crude protein & 26.12 & 25.83 & 25.79 & 25.73 & 25.78 \\
\hline Ether extract & 6.67 & 6.09 & 6.12 & 6.33 & 6.56 \\
\hline Crude fibre & 8.43 & 7.8 & 8.09 & 8.5 & 8.12 \\
\hline Ash & 7.86 & 7.7 & 7.13 & 7.45 & 7.49 \\
\hline Nitrogen free extract & 50.92 & 52.58 & 52.87 & 51.99 & 52.05 \\
\hline \multicolumn{6}{|l|}{ Fatty acid composition (\%) } \\
\hline$\sum \mathrm{SFA}$ & 22.68 & 23.24 & 24.95 & 25.113 & 25.84 \\
\hline$\sum$ MUFA & 49.17 & 47.41 & 48.131 & 47.26 & 48.62 \\
\hline$\sum$ PUFA n-6 & 23.96 & 24.82 & 24.92 & 24.86 & 23.96 \\
\hline$\sum$ PUFA n-3 & 0.38 & 0.40 & 0.55 & 0.44 & 0.42 \\
\hline Total & 96.20 & 95.87 & 98.55 & 97.66 & 98.85 \\
\hline
\end{tabular}

"Supplevite - M (Jeco Vet Chem Pvt. Ltd, Mumbai, India) Each 1 kg of Supplevite - M contains: Vitamin A: 200000 IU, Vitamin D: 40000 IU, Vitamin $B_{2}: 0.8$ g, Vitamin E: 300 IU, Vitamin K: 400 g, Calcium panthonate: 1 g, Nicotinamide: 4 g, Vitamin $B_{12}: 2.4$ mg, Choline chloride: 60 g, Calcium: $300 \mathrm{~g}$, Manganese: $11 \mathrm{~g}$, Iodine: $0.4 \mathrm{~g}$, Iron: 3 . g, Zinc: $6 \mathrm{~g}$, Copper: $0.8 \mathrm{~g}$, Cobalt: $0.18 \mathrm{~g}$.

The data are presented as mean $\pm \mathrm{SE}$, Means bearing different superscripts in a row differ significantly $(\mathrm{p}<0.05)$

Table 3. Carcass composition of Labeo rohita fingerlings fed different test feeds containing polanga oil cake for 90 days ( $\%$ DM basis)

\begin{tabular}{|c|c|c|c|c|c|c|}
\hline \multirow{2}{*}{ Parameters } & \multirow{2}{*}{ Initial } & \multicolumn{5}{|c|}{ Test feeds of L. rohita } \\
\hline & & $\mathrm{F} 1$ & $\mathrm{~F} 2$ & $\mathrm{~F} 3$ & $\mathrm{~F} 4$ & F5 \\
\hline \multicolumn{7}{|l|}{$\begin{array}{l}\text { Proximate } \\
\text { composition }\end{array}$} \\
\hline Moisture & $79.69 \pm 0.07$ & $77.7 \pm 0.08^{\mathrm{ab}}$ & $77.1 \pm 0.17^{\mathrm{a}}$ & $78.8 \pm 0.2^{\mathrm{bc}}$ & $79.3 \pm 0.8^{\mathrm{c}}$ & $79.9 .0 \pm 0.9^{\mathrm{c}}$ \\
\hline $\mathrm{CP}$ & $64.86 \pm 0.21$ & $66.13 \pm 0.03^{c}$ & $67.33 \pm 0.61^{\mathrm{c}}$ & $66.24 \pm 0.21^{\mathrm{b}}$ & $66.09 \pm 0.11^{\mathrm{ab}}$ & $65.47 \pm 0.03^{\mathrm{a}}$ \\
\hline $\mathrm{EE}$ & $9.40 \pm 0.06$ & $14.28 \pm 0.09^{c}$ & $14.56 \pm 0.05^{\mathrm{c}}$ & $12.86 \pm 0.06^{\mathrm{b}}$ & $11.39 \pm 0.0^{\mathrm{a}}$ & $10.56 \pm 0.05^{\mathrm{a}}$ \\
\hline Ash & $23.42 \pm 0.18$ & $16.45 \pm 0.02^{\mathrm{ab}}$ & $15.24 \pm 0.15^{\mathrm{a}}$ & $17.93 \pm 0.05^{\mathrm{b}}$ & $19.66 \pm 0.01^{\mathrm{c}}$ & $21.23 \pm 0.01^{\mathrm{d}}$ \\
\hline \multicolumn{7}{|l|}{ Fatty acid } \\
\hline$\sum \mathrm{SFA}$ & 27.71 & 26.25 & 24.33 & 24.61 & 27.25 & 28.58 \\
\hline$\sum$ MUFA & 43.70 & 44.92 & 43.12 & 42.38 & 41.97 & 40.37 \\
\hline$\sum$ PUFA n-6 & 15.44 & 18.12 & 18.44 & 18.21 & 18.04 & 18.05 \\
\hline$\sum$ PUFA n-3 & 2.82 & 4.08 & 4.40 & 4.64 & 5.46 & 6.94 \\
\hline Total & 89.67 & 93.37 & 90.29 & 89.84 & 92.72 & 93.93 \\
\hline
\end{tabular}

The data are presented as mean $\pm \mathrm{SE}$

Means bearing different superscripts in a row differ significantly $(\mathrm{p}<0.05)$

There was a linear increase in final whole body moisture content in the groups fed with POC containing feeds from $20-40 \%$ incorporation. Reverse trend was observed in case of ether extract contents. The final whole body ash content differed significantly $(\mathrm{p}<0.05)$ in all the groups with an increasing trend having increased level of POC incorporation.
Phenol, tannin, flavonoids, alkaloids, glycoside and saponin were detected as phytochemicals in TOC. Among all these phytochemicals, tannin, phenol and flavonoids were found to be more (based on visual estimation) compared to other phytochemicals tested in the present study (Table 1). The fatty acid profile of POC and test feed is given in Table 1 and 2. 
Table 4. Survival, growth and nutritional indices of Labeo rohita fingerlings fed different levels of polanga oil cake incorporated diets

\begin{tabular}{llllll}
\hline \multirow{2}{*}{ Parameters } & \multicolumn{5}{c}{ Test feeds of L. rohita } \\
\cline { 2 - 6 } & F1 (0\% POC) & F2 (10\% POC) & F3 (20\% POC) & F4 (30\% POC) & F5 (40\% POC) \\
\hline Survival (\%) & $95.45 \pm 2.62^{\mathrm{b}}$ & $96.97 \pm 1.52^{\mathrm{b}}$ & $95.45 \pm 2.62^{\mathrm{b}}$ & $84.85 \pm 1.52^{\mathrm{a}}$ & $77.27 \pm 5.25^{\mathrm{a}}$ \\
Av. int. wt. (g) & 5.76 & 5.53 & 5.45 & 5.15 & 5.23 \\
Wt. gain (g) & $1.91 \pm 0.18^{\mathrm{b}}$ & $2.04 \pm 0.14^{\mathrm{b}}$ & $0.78 \pm 0.14^{\mathrm{a}}$ & $0.56 \pm 0.10^{\mathrm{a}}$ & $0.57 \pm 0.24^{\mathrm{a}}$ \\
Wt. gain (\%) & $33.40 \pm 4.02^{\mathrm{b}}$ & $37.12 \pm 3.41^{\mathrm{b}}$ & $14.32 \pm 1.33^{\mathrm{a}}$ & $11.07 \pm 1.09^{\mathrm{a}}$ & $10.88 \pm 1.60^{\mathrm{a}}$ \\
SGR (\% day $\left.{ }^{-1}\right)$ & $0.48 \pm 0.05^{\mathrm{b}}$ & $0.53 \pm 0.04^{\mathrm{b}}$ & $0.22 \pm 0.04^{\mathrm{a}}$ & $0.17 \pm 0.03^{\mathrm{a}}$ & $0.17 \pm 0.07^{\mathrm{a}}$ \\
FCR & $3.62 \pm 0.27$ & $3.24 \pm 0.19$ & $9.09 \pm 0.84$ & $12.56 \pm 1.69$ & $13.80 \pm 1.85$ \\
PER & $1.12 \pm 0.08^{\mathrm{b}}$ & $1.20 \pm 0.05^{\mathrm{b}}$ & $0.48 \pm 0.08^{\mathrm{a}}$ & $0.36 \pm 0.06^{\mathrm{a}}$ & $0.42 \pm 0.16^{\mathrm{a}}$ \\
NPU (\%) & $16.7 \pm 0.09^{\mathrm{c}}$ & $17.8 \pm 0.07^{\mathrm{c}}$ & $7.53 \pm 0.04^{\mathrm{b}}$ & $5.15 \pm 0.05^{\mathrm{a}}$ & $5.28 \pm 0.07^{\mathrm{a}}$ \\
\hline
\end{tabular}

The data are presented as mean $\pm \mathrm{SE}$

Means bearing different superscripts in a row differ significantly $(\mathrm{p}<0.05)$.

SGR: Specific growth Rate; FCR: Feed conversion ratio; PER: Protein efficiency ratio, NPU: Net protein utilisation

The $\sum$ MUFA and $\sum$ PUFA n-6 content of POC was recorded as 39 and $28 \%$, respectively. Some blood parameters viz., haemoglobin, glucose, serum protein, serum albumin, serum globulin, triglyceride, cholesterol, LDL, HDL, VLDL and serum enzymes like GOT and GPT of the fish grown in all the feeding group were studied. Haemoglobin, serum protein and albumin, cholesterol HDL and LDL content were similar in F1 and F2 but gradually decreased with increasing levels of POC in feed (F3-F5). Triglycerides and VLDL did not show significant variation $(\mathrm{p}>0.05)$ among all the feeding groups. In serum GOT and GPT, an increasing trend was observed $(\mathrm{p}<0.05)$ with increasing level of POC in the feed (F3-F5). Similar trend was observed for blood glucose level (Table 5).

\section{Discussion}

The nutritive value of POC and its varied use has been studied by a few workers (Lim, 2012; Chavan et al., 2013).
Attempts were made to incorporate POC in the feed of poultry to reduce the feed cost (Dash et al., 1990; Mishra et al., 2005). So far, no information is available on the use of POC as feed ingredient for fish particularly in carps (www.feedipedia.org). Crude protein content of the POC as reported by earlier authors varied from 22-27\% (Behura et al.,1987; Mohapatra and Samal, 2002). In the present study, the CP and NFE value of POC were $24 \%$ and $53 \%$, respectively and therefore, it could be used as a source of protein and energy in the test feeds. Mohanty et al. (2011) mentioned that threonine, lysine and tryptophan requirement of L. rohita is $4.28,5.58$ and $1.3 \%$ of protein, respectively. The amino acid profile of POC was studied by Mohapatra and Samal (2002). They reported that threonine, lysine and tryptophan content of POC are at $0.89,1.4$ and $0.38 \%$ of protein, respectively, whereas, same in groundnut oil cake are reported at $1.42,1.82$ and $1.0 \%$ of protein, respectively

Table 5. Blood constituents of Labeo rohita fingerlings fed different levels of polanga oil cake

\begin{tabular}{|c|c|c|c|c|c|}
\hline Attributes & $\begin{array}{l}\text { Feed-1 } \\
(0 \% \text { POC) }\end{array}$ & $\begin{array}{l}\text { Feed-2 } \\
(10 \% \text { POC) }\end{array}$ & $\begin{array}{l}\text { Feed-3 } \\
(20 \% \text { POC) }\end{array}$ & $\begin{array}{l}\text { Feed-4 } \\
(30 \% \text { POC) }\end{array}$ & $\begin{array}{l}\text { Feed-5 } \\
(40 \% \text { POC) }\end{array}$ \\
\hline Haemoglobin $\left(\mathrm{g} \mathrm{dl}^{-1}\right)$ & $6.92 \pm 0.13^{\mathrm{b}}$ & $7.78 \pm 0.66^{\mathrm{b}}$ & $5.86 \pm 0.19^{\mathrm{a}}$ & $5.65 \pm 0.09^{\mathrm{a}}$ & $4.83 \pm 0.07^{\mathrm{a}}$ \\
\hline Glucose $\left(\mathrm{mg} \mathrm{dl}^{-1}\right)$ & $238.1 \pm 15.7^{a}$ & $241.0 \pm 6.0^{\mathrm{a}}$ & $252.8 \pm 8.3^{\mathrm{b}}$ & $288.9 \pm 12.3^{\mathrm{c}}$ & $290.5 \pm 6.0^{c}$ \\
\hline Protein $\left(\mathrm{g} \mathrm{dl}^{-1}\right)$ & $4.40 \pm 0.04^{\mathrm{c}}$ & $4.37 \pm 0.05^{\mathrm{c}}$ & $4.13 \pm 0.01^{\mathrm{b}}$ & $4.10 \pm 0.02^{\mathrm{b}}$ & $3.83 \pm 0.01^{\mathrm{a}}$ \\
\hline Albumin $\left(\mathrm{g} \mathrm{dl}^{-1}\right)$ & $1.47 \pm 0.01^{\mathrm{c}}$ & $1.48 \pm 0.01^{\mathrm{c}}$ & $1.38 \pm 0.01^{\mathrm{b}}$ & $1.40 \pm 0.01^{\mathrm{b}}$ & $1.27 \pm 0.01^{\mathrm{a}}$ \\
\hline Globulin $\left(\mathrm{g} \mathrm{dl}^{-1}\right)$ & $2.94 \pm 0.02^{\mathrm{c}}$ & $2.89 \pm 0.06^{\mathrm{c}}$ & $2.84 \pm 0.03^{\mathrm{bc}}$ & $2.75 \pm 0.01^{\mathrm{b}}$ & $2.56 \pm 0.01^{\mathrm{a}}$ \\
\hline SGOT $\left(\mathrm{u} \mathrm{l}^{-1}\right)$ & $139.87 \pm 2.59^{\mathrm{a}}$ & $142.22 \pm 1.05^{\mathrm{a}}$ & $192.77 \pm 0.51^{\mathrm{b}}$ & $271.23 \pm 0.52^{\mathrm{c}}$ & $375.58 \pm 2.56^{\mathrm{d}}$ \\
\hline SGPT $\left(\mathrm{u} \mathrm{l}^{-1}\right)$ & $15.91 \pm 0.34^{\mathrm{a}}$ & $16.36 \pm 1.51^{\mathrm{a}}$ & $18.94 \pm 1.04^{\mathrm{ab}}$ & $20.71 \pm 1.03^{\mathrm{b}}$ & $39.58 \pm 0.60^{\mathrm{c}}$ \\
\hline Triglyceride $\left(\mathrm{mg} \mathrm{dl}^{-1}\right)$ & $228.93 \pm 9.52^{\mathrm{a}}$ & $249.06 \pm 5.24^{\mathrm{a}}$ & $247.38 \pm 4.67^{\mathrm{a}}$ & $249.90 \pm 6.05^{\mathrm{a}}$ & $249.90 \pm 2.22^{\mathrm{a}}$ \\
\hline Cholesterol ( $\left.\mathrm{mg} \mathrm{dl}^{-1}\right)$ & $182.13 \pm 1.67^{\mathrm{c}}$ & $182.02 \pm 1.56^{\mathrm{c}}$ & $177.78 \pm 0.78^{\mathrm{b}}$ & $172.08 \pm 0.87^{\mathrm{a}}$ & $170.18 \pm 0.19^{\mathrm{a}}$ \\
\hline $\operatorname{HDL}\left(\mathrm{mg} \mathrm{dl}^{-1}\right)$ & $58.08 \pm 0.91^{\mathrm{c}}$ & $55.84 \pm 1.44^{\mathrm{c}}$ & $51.84 \pm 0.28^{\mathrm{b}}$ & $46.32 \pm 1.74^{\mathrm{a}}$ & $42.8 \pm 0.68^{\mathrm{a}}$ \\
\hline $\operatorname{LDL}\left(\mathrm{mg} \mathrm{dl}^{-1}\right)$ & $128.80 \pm 0.24^{\mathrm{b}}$ & $129.04 \pm 0.83^{\mathrm{b}}$ & $127.16 \pm 1.33^{\mathrm{b}}$ & $127.28 \pm 1.04^{b}$ & $121.39 \pm 2.76^{\mathrm{a}}$ \\
\hline $\operatorname{VLDL}\left(\mathrm{mg} \mathrm{dl}^{-1}\right)$ & $45.79 \pm 1.90^{\mathrm{a}}$ & $49.81 \pm 1.05^{\mathrm{a}}$ & $49.48 \pm 0.93^{\mathrm{a}}$ & $49.98 \pm 1.21^{\mathrm{a}}$ & $49.98 \pm 0.44^{\mathrm{a}}$ \\
\hline
\end{tabular}

The data are presented as mean $\pm \mathrm{SE}$

Means bearing different superscripts in a row differ significantly $(\mathrm{p}<0.05)$. SGOT: Serum glutamic oxaloacetic transaminase; SGPT: Serum glutamic pyruvic transaminase, HDL: High-density lipoprotein LDL: Low-density lipoprotein; VLDL: Very low-density lipoprotein 
(Babiker, 2012). Therefore, POC incorporation in higher percentage in the test diet certainly reduced the contribution of these essential amino acids in the test feeds. Hence, growth retardation due to increase in POC level may be attributed to the above limiting essential amino acids as one of the factor. The fatty acid contribution of POC and POC containing feed is reflected in the carcass composition. Increasing trend of PUFA in the carcass may be influenced by the level of POC incorporation in feed but certainly it did not contribute to overall growth performance of the fish. Ether extract (EE) of POC was predominantly composed of oleic acid (C18:1) 39\%, followed by linoleic acid (C18:2) 27\%, stearic acid (18:0) 11\% and palmitic acid (C16:0) 15\%. Crane et al. (2005) revealed the presence of the above fatty acids in Calophyllum inophyllum oil in the range of 39-50\%, 21-31\%, $13-14 \%$ and $11-13 \%$, respectively. $\sum$ PUFA n-6 and $\sum$ PUFA $\mathrm{n}-3$ of POC in the present study are found as 28 and $0.4 \%$, respectively. Similar result was also reported by Chavan et al. (2013). Phytochemicals viz., tannin, saponin, alkaloids, resins and flavonoids, detected in the present study were in agreement with the findings of other workers (Balogun and Ogunniyi, 2012; Indrakumar et al., 2012). Bhushan et al. (1975) reported calaustralin, a 4-phenyl-coumarin from seed of Calophyllum inophyllum as a non-fatty toxic constituent. Obviously, calaustralin content of the test feed increased with increased level of POC incorporation. This may be another factor for reducing growth and survival in higher POC incorporated feed groups. Mukhopadhyay and Ray (1999) opined that tannin in higher concentrations reduce feed intake and affect protein and carbohydrate digestibility, though beneficial in lower concentration in fish feed. Francis et al. (2001) further clarified that tannin at higher concentration affects protein utilisation, because it binds to lysine and makes this essential amino acid unavailable to monogastric animals and fish. The fish feed containing higher level of alkaloids reduces the feed intake due to its anti-palatabilty property (Glencross et al., 2006). Feed intake, FCR, weight gain $\%$ and SGR were similar in 0 and $10 \%$ incorporation of POC. However, feed intake and all the growth parameters reduced with increasing levels of POC incorporation in feed. There is no published literature available in fish to compare the present findings but incorporation of POC in poultry feed resulted in growth depression at more than $5 \%$ inclusion levels (Behura et al., 1987; Dash et al., 1990). Bhehura et al. (1987) reported that inclusion of POC at 10 and $15 \%$ level caused growth depression in chicks but it did not have any remarkable changes in haematological and biochemical parameters of blood or any pathological changes observed in any of the vital organs. Mishra et al. (2005) observed that inclusion of POC at $5 \%$ level in the diet of RIR chicks had no adverse effect on the growth performance and could partially replace the conventional protein sources. In the present study, the changes in hematological parameters viz., haemoglobin, serum protein, serum albumin, serum globulin, triglycerides and cholesterol were non-significant in F1 and F2 groups $(p>0.05)$, but reduced significantly $(p<0.05)$ with increased levels of POC in the feeds $(20-40 \%)$. Lower blood glucose level was observed in F1 and F2 groups which increased significantly at higher incorporation levels of POC in feeds (F3-F5). Das et al. (2004) observed that blood glucose level of $L$. rohita fingerlings increased when they were exposed to stress factors. In the present study, the blood glucose level of the fingerlings increased significantly in the groups F3-F5, may be due to the physiological stress. Serum GOT and GPT are two enzymes considered as biological indicators of hepatic health. Hegab et al. (1993) opined that in hepatic toxicity, these enzymes are increased and liberated into blood. In the present study, increased levels of serum GOT and GPT recorded in F3-F5 fed groups could be attributed to the effect of higher inclusion of POC in the feeds. Hepatic toxicity and increased levels of GOT and GPT due to chemical pollutants are also reported in carps by Parvathi et al. (2011) and Chavan and Muley (2014).

Efforts are being made to replace the conventional protein sources by non-conventional ones in fish diets. Hossain et al. (2001) added $10 \%$ of Sesbania aculeata seed meal to the diet of common carp and tilapia as non-conventional ingredient without compromising growth. Similar result was reported by Aanyu et al. (2012) in tilapia with cotton seed cake incorporation at $20 \%$ level. Rath et al. (2014) replaced groundnut oil cake and rice bran at $150 \mathrm{~g}$ each with incorporation of $300 \mathrm{~g}$ rain tree pod meal $\mathrm{kg}^{-1}$ feed in L. rohita larval diet. Presently, inclusion of $100 \mathrm{~g}$ of raw POC as non-conventional ingredient could replace $40 \mathrm{~g}$ of groundnut oil cake and $60 \mathrm{~g}$ of rice bran $\mathrm{kg}^{-1}$ feed without compromising the survival and growth of L. rohita fingerlings, fed for 90 days. Moreover, POC is considered as a low-priced oil cake than groundnut oil cake and rice bran. However, the present study revealed that there is scope to use $100 \mathrm{~g}$ raw POC $\mathrm{kg}^{-1}$ feed for L. rohita fingerlings without compromising survival and growth. However, more detailed studies are required to fill the gaps in knowledge for the possible detoxification to increase the incorporation rate (Abbeddou and Makkar, 2012).

Raw POC could be used as non-conventional plant protein source up to $10 \%$ level in the feed of L. rohita fingerlings without any adverse effect on its growth and survival and could partially replace the conventionally used costly groundnut oil cake and rice bran. The incorporation level may further be increased by suitable processing of POC. POC as a non-conventional feed ingredient in carp feed is being reported for first time in this present study. 


\section{Acknowledgements}

Authors are grateful to Dr. P. Jayasankar, former Director, ICAR-CIFA, Kausalyaganga, Bhubaneswar, India for providing all required facilities to conduct the experiment. The help rendered by Ms. Nibedita Rana, TMP-II and Ms. Prgyn Priyadarsini Mohanty TMP-II, Fish Nutrition and Physiology Division, ICAR-CIFA, Bhubaneswar is duly acknowledged.

\section{References}

Allain, C. C., Poon, L. S., Chan, C. S. G., Richmond, W. and Fu, P. C. 1974. Enzymatic determination of total serum cholesterol. Clin. Chem., 20: 470-475.

Aanyu, M., Carpaij, C. and Widmer, M. 2012. Effect of diets with graded levels of inclusion of cotton and sunflower seed cakes on the growth performance and feed utilisation of Nile tilapia, Oreochromis niloticus. Livestock Res. Rural Dev., 24(5): Article \#84.

Abbeddou, S. and Makkar, H. P. S. 2012. Potential and constraints in utilising co-products of the non-edible oils-based biodiesel industry - an overview. In: Makkar, H. P. S. (Ed.), Biofuel coproducts as livestock feed - Opportunities and challenges, Rome, p. 325-338.

AOAC 1990. Official methods of analysis. Association of Official Analytical Chemists, Arlington, VA, USA, p. 69-78.

APHA 1989. Standard methods for the examination of water and waste water. American Public Health Association, New York, USA, 1193 pp.

Babiker, M. S. 2012. Chemical composition of some nonconventional and local feed resources for poultry in Sudan. Int. Poult. Sci., 11: 283-287.

Balogun, O. S. and Ogunniyi, D. R. 2012. Chemical and biological assessment of Calophyllum inophyllum (Linn) seed oil. Pharmacologyonline, 3: 58-62.

Barman, B. K. and Karim, M. 2007. Analysis of feeds and fertilisers for sustainable aquaculture development in India. In: Hasan, M. R., Hecht, T., De Silva, S. S. and Tacon, A. G. J. (Eds.), Study and analysis of feeds and fertilisers for sustainable aquaculture development. FAO Fisheries Technical Paper No. 497, Rome, Italy, p. 113-140.

Behura, N. C., Sahu, B. K., Panda, N. C. and Dehuri P. K. 1987. Feeding value of polanga (Calophyllum inophyllum) oil meal in chick ration. Indian J. Poult. Sci., 22: 203-206.

Bergmeyer, H. L. 1974. Methods of ensymatic analysis, $2^{\text {nd }}$ edn. Academic Press, New York.

Bhushan, B., Rangaswami, S. and Seshadri, T. R. 1975. Calaustralin, a new 4-Phenylcoumarin from the seed oil of Calophyllum inophyllum Linn. Indian J. Chem., 13: 746-747.

Burtis, C. A. and Ashwood, E. R. 1994. Tietz textbook of clinical chemistry, $2^{\text {nd }}$ edn. Sauners, Philadelphia.
Chavan, S. B., Kumbhar, R. R. and Deshmukh, R. B. 2013. Calophyllum inophyllum Linn ("honne") oil, A source for biodiesel production. Res. J. Chem. Sci., 3: 24-31.

Chavan, V. R. and Muley, D. V. 2014. Effect of heavy metals on liver and gill of fish Cirrhinus mrigala. Int. J. Curr. Microbiol. App. Sci., 3: 277-288.

Crane, S., Aurore, G., Joseph, H., Mouloungui, Z. and Bourgeois, P. 2005. Composition of fatty acids triacylglycerols and unsaponifiable matter in Calophyllum calaba L. oil from Guadeloupe. Phytochemistry, 66: 1825-1831.

Cristie, W. W. 1982. Lipid analysis. Pergamon Press, Oxford, p. 17-23.

Das, P. C., Ayyappan, S., Jena, J. K. and Das, B. K. 2004. Effect of sub-lethal nitrate toxicity on the haematological parameters of fingerlings of Labeo rohita (Ham.). Indian J. Fish., 51: $287-294$

Dash, P. K., Sahu, B. K., Dehuri, P. K., Panda, N. C. and Mishra, S. C. 1990. Defatted polanga Calophyllum inophyllum oilcake as feedstuff for broilers. Indian J. Poult. Sci., 25: $256-60$

Doumas, B. T., Watson, W. and Biggs, H. G. 1971. Albumin standards and the measurement of serum albumin with bromcresol green. Clin. Chim. Acta, 31: 87-96.

Evans, W. C. 2000. Trease and Evan pharmacology, $14^{\text {th }}$ edn. WB Saunders Company Ltd., p. 224-293.

Flack, C. P. and Woollen, J. W. 1984. Prevention of interference by dextran with biuret-type assay of serum protein. Clin. Chem. 30: $559-561$.

Folch, A. C., Leeds, M. and Sloane-Stanley, G. M. 1957. A simple method for isolation and purification total lipids from animal tissues. J. Biol. Chem., 226: 497-509.

FAO 2010. The state of world fisheries and aquaculture. FAO Fisheries and Aquaculture Department, Rome, Italy.

Francis, G., Makkar, H. P. and Becker, S. K. 2001. Anti-nutritional factors present in plant-derived alternate fish feed ingredients and their effects in fish. Aquaculture, 199: 197-227.

Glencross, B., Evans, D., Rutherford, N., Hawkins, W., Mc Cafferty, P., Dods, K., Jones, B., Harris, D., Morton, L., Sweetingharn, M. and Sipsas, S. 2006. The influence of dietary inclusion of alkaloid gramine on rainbow trout (Oncorhynchus mykiss) growth, feed utilisation and gastrointestinal histology. Aquaculture, 253: 512-522.

Harbone, J. B. 1998. Phytochemical methods - A guide to modern techniques of plant analysis. Chapman and Hall, London, p. 182-190.

Hasan, M. R., Hecht, T., De Silva, S. S. and Tacon, A. G. J. 2007. Study and analysis of feeds and fertilisers for sustainable aquaculture development. FAO Fisheries Technical Paper No. 497, Rome, Italy, $510 \mathrm{pp}$.

Hegab, A. S., Kamel, M. G. E. and Labib, W. D. 1993. Some biochemical indices of the pesticides tamaron and bayluscide in the freshwater Tilapia: Oreochromis niloticus. Proc. Zool. Soc., 24: 183-197. 
Hossain, M. A., Focken, U. and Becker, K. 2001. Evaluation of an unconventional legume seed, Sesbania aculeata, as a dietary protein source for common carp, Cyprinus carpio L. Aquaculture, 198: 129-140.

Indrakumar, I., Selvi, V., Gomathi, R. and Karpagam, S. 2012. Phytochemical analysis of leaf extracts of Calophyllum inophyllum L. and Cananga odorata (Lam.). J. Pharm. Biol. Sci., 3: 35-37.

Kaplan, L. A. 1984. Carbohydrates and metabolite In: Mosby, C. V. and Toronto, P. (Eds.), Clinical chemistry, p. 1032-1040.

Lim, T. K. 2012. Calophyllum inophyllum. In: Edible medicinal and non-medicinal plants, vol. 2, Springer Dordrecht Heidelberg London New York, p. 7-20.

Manomaitis, L. 2009. Improving South-east Asian aquaculture through feeds and technology. $17^{\text {th }}$ Annual ASAIM SEA Feed Technology and Nutrition Workshop, Vietnam, p. 15-19.

McGowan, M. W., Artiss, J. D., Strandbergh, D. R. and Zak, B. 1983. A peroxidase-coupled method for the colorimetric determination of serum triglycerides. Clin. Chem., 29: $538-542$

Mishra, S. K., Sahu, B. K., Swain, R. K. and Mishra, S. C. 2005. Use of unconventoinal protein supplements in the ration of chicks. Indian J. Anim. Nutr., 22: 263-265.

Mohanty, S. N., Giri, S. S., Rath, S. C. and Mohanta, K. N. 2011. Nutrition of finfishes and shellfishes. In: Handbook of fisheries and aquaculture. Indian Council of Agricultural Research, New Delhi, p. 734 -761.

Mohanty, S. N., Rath, S. C., Mohanta, K. N., Sali, S.A. and Giri, S. S. 2013. Oil seed residues In: Fish feed resources and farm made feed. Indian Council of Agricultural Research,
New Delhi and Central Institute of Freshwater Aqaculture, Bhubaneswar, p. 24-25.

Mohapatra, A. K. and Samal, P. C. 2002. Limiting amino acids of Polanga (Calophyllum inophyllum) oil cake in chicks. Indian J. Anim. Nutr., 19: 285-288.

Mukhopadhyay, N. and Ray, A. K. 1999. Utilisation of copra meal in the formulation of compound diets for rohu, Labeo rohita fingerlings. J. Appl. Ichthyol., 15: 127-131.

Parvathi, K., Sivakumar, P., Ramesh, M. and Sarasu 2011. Sublethal effects of chromium on some biochemical profiles of the freshwater teleost, Cyprinus carpio. Int. J. Appl. Biol. Pharm., 2: 295-300.

Rath, S. C., Nayak, K. C., Mohanta, K. N., Pradhan, C., Rangacharyulu, P. V., Sarkar, S. and Giri, S. S. 2014. Nutritional evaluation of rain tree (Samanea saman) pod and its incorporation in the diet of Labeo rohita larvae as a nonconventional feed ingredient. Indian J. Fish., 61: 105-111.

Sahu, N. P., Sahu, B. K., Dehuri, P. K., Panda, N. C. and Mishra, S. C. 1993. Effect of feeding polanga oil cake on egg production, egg quality and hatchability of white leghorn layers. Indian $J$. Poult. Sci., 28: 32-35.

Snedecor, G. W. and Cochran, W. 1967. Statistical methods. $6^{\text {th }}$ edn., Oxford and IBH, New Delhi, p. 1-593.

Van Kampen, E. J. and Zijlstra, W. G. 1961. Standardisation of hemoglobinometry II. The hemoglobincyamide method. Clin. Chem. Acta, 6: 538-544. 